\title{
A BRITISH TOUCH ON TANZIMAT: ARCHITECT WILLIAM JAMES SMITH
}

\section{Tanzimat'a İngiliz Dokunuşu: Mimar William James Smith* Esma İGÜS ${ }^{* *}$}

\begin{abstract}
This article examines the life and works of British architect William James Smith and outlines his contributions to nineteenth century Ottoman architecture and presents his prominence as an architectural historian of nineteenth century British architectural work.
\end{abstract}

Key Words: Tanzimat, Ottoman architecture, William James Smith

Özet: $\mathrm{Bu}$ makale Osmanlı İmparatorluğu adına çalışan ilk yabancı mimarlardan biri olan İngiliz Mimar William James Smith'in hayatını ve eserlerini inceleyerek Smith'in XIX. yüzyıl Osmanlı mimarlığındaki yerini ve Osmanlı mimarisine yaptığı katkıları tespit etmekte ve XIX. yüzyıl İngiltere'si mimarlık dünyasında, mimarlık tarihi yazarı olarak da varlık gösterdiğini tespit etmektedir.

Anahtar Kelimeler: Tanzimat, Osmanlı mimarlığı, William James Smith

\section{Introduction}

After a short period of royal residence in the former capital Adrianople (Edirne), the return of Ahmed III (r. 1703-30) to Istanbul triggered changes in traditional settlements and the physical environment of Istanbul and other Ottoman cities and this process proceeded with further professionalism in architecture. ${ }^{1}$ This modernization was a process of planned urbanization and transformation; the face and appearance of Ottoman cities transformed as did the mind-set of ruling elite. ${ }^{2}$ The revisionism in architecture not only made new structures visible in Ottoman cities but also brought changes in building technics and materials used. During the Tanzimat (reorganization) or most commonly known reform period (1839-1876) of

\footnotetext{
* This article is an outcome of research titled "The British Influence on Ottoman Architecture During the Tanzimat (Reorganization) Period: William James Smith.” The research was conducted in London between July and October 2013 with the funding of Turkish Council of Higher Education.

** (Assist. Prof. Dr.), Mimar Sinan Güzel Sanatlar Üniversitesi, Meslek Yüksekokulu, Mimari Restorasyon Program1, Türkiye/İstanbul, e-mail: esma.igus@msgsu.edu.tr

${ }^{1}$ The most significant change in the settlement of Istanbul started in the eighteenth and the nineteenth centuries, when new settlements were established outside the city walls. The shores of the Bosphorous and Golden Horn became new residential areas for the Ottoman elite. This shift brought along new architectural styles and decorations. Shirine Hamadeh, Şehr-i Sefa 18. Yüzyılda İstanbul, İletişim Yayınları, İstanbul 2010, p.20; the Ottoman sultan's return to Istanbul helped the city to regain its position as a cultural and intellectual center. Bahar Deniz Çalış, Ideal and Real Spaces of Ottoman Imagination: Continuity and Change in Ottoman Rituals of Poetry (Istanbul, 14531730), Unpublished Dissertation, Middle East Technical University, Ankara 2004, p. 4.

${ }^{2}$ Initiation of new property laws in the nineteenth century eased private property ownership and made the transformation of Istanbul possible. Ayşe Derin Öncel, Apartman, Galata'da Yeni Bir Konut Tipi, Kitap Yayınevi, İstanbul 2010, p. 9-10; Esma İgüs, "XVIII. Yüzyıl İstanbul'unda Fiziki Çevre, Meydan Çeşmeleri ve Çeşme Meydanlarının Etrafinda Oluşan İstanbul Meydanları', in Osmanlı İstanbul'u II, II. Uluslararası Osmanlı İstanbul'u Sempozyumu Bildirileri 27-29 Mayls 2014, İstanbul 29 Mayls Üniversitesi, İstanbul 29 May1s Üniversitesi Yayınları, İstanbul 2015, p. 675.
} 
the Ottoman Empire, Western architects such as Antoine Ignaz Melling, ${ }^{3}$ the Fossati Brothers, ${ }^{4}$ and William James Smith became influential in the architectural transformation of Istanbul. With the support of the Ottoman ruling elite, these architects worked freely to carry European aesthetics with similar styles to structures in Istanbul. This article examines the impact of Smith's architectural work in Istanbul. Traditional Ottoman architecture is known for its massive structures, funded by the Ottoman ruling class and highlighted the Ottoman identity. As the superiority of Western science and technology were acknowledged in the Tanzimat period, the Ottomans embraced Western architecture. This article presents that Smith became one of the leading Western architects, who carried Europen and particularly Anglo-Saxon architectural tradition along with a European eclectic architectural approach and interior designs to Istanbul.

\section{The Impact of Tanzimat on Ottoman Architecture and Foreign Architects}

Since the late fifteenth century, some European port cities gradually grew as highcapacity ports in the merchantilist then later capitalist world trade system. With the help of trade, agricultural cash crops, and raw materials brought from the colonies, European cities became wealthier and in the nineteenth century European cities turned into industrial hubs. Industrialization and wealth attracted rural masses to the cities and caused a demographic shift, which required new and professional urban management and municipal services. ${ }^{5}$

As the financial power of Eurpeaan churches and monarchies were overshadowed by the emerging business class, massive imperialist and spiritual structures were replaced by structures built for esthetic and pragmatic earthly needs. ${ }^{6}$ New architectural styles, such neoclassic, Empire style and Gothic Revival (Victorian Gothic) and Eclectic were added to the European architectural catalogue. ${ }^{7}$ Perhaps one of the most popular architectural styles was neoclassic style. In the aftermath of French Revolution (1789) and Greek Independence (1829), the idea of democaracy and freedom were gradually embraced as European ideals and ancient Greek and Roman civilization were revived in the arts and architecture. ${ }^{8}$ In the last quarter of nineteenth century, the eclectic style, which harmonized various features of other styles, joined the architectural milieu. While new styles emerged in nineteenth century Europe, protectionism helped to preserve some historical structures as they were deemed national treasures. Artists and novelists played a crucial role in the preservation of historical structures. In his famous 1831 novel, Nôtre Dame de Paris, Victor Hugo selected the medieval cathedral as the central theme of his work rather than a person and attracted the attention of educated elite to this medieval

\footnotetext{
${ }^{3}$ Antoine Ignace Melling or Anton Ignaz Melling (1763-1831) was a German painter, architect and traveller. Melling visited Istanbul for a few months in 1784 as a traveller but stayed there eighteen years. He was the first German architect who worked for the Ottoman court as the private architect of Hatice Sultan, sister of Ottoman Sultan Selim III (r. 1789-1807). Melling continued his artistic work in Paris, where he moved in 1802. In 1809 he published an album with panaromic views of Istanbul, Voyage pittoresque de Constantinople et des rives du Bosphore, Strassburg and London: Treuttel et Würtz, [1809]-1819. Joseph Thomas, Universal Pronouncing Dictionary of Biography and Mythology, V. II., J. B. Lippincot, Philedelphia 1870, p. 1564. Özlem Atalan, “17. ve 18. Yüzyılda Görsel ve Yazılı Kaynaklara Göre Ortaköy- Kuruçeşme Arasında Yer Alan Kıyı Yapıları” JASS, 2014 (28), p. 235.

${ }^{4}$ Italian architects Gaspare Fossati (1809-1883) and his brother Guisseppe Fossati (1822-1891) came to Istanbul in 1837 to construct a new Russian Embassy building. Because their work was found successful in the Ottoman Empire, they were assigned other building projects. The most significant work they did in Istanbul was the renovation of Hagia Sophia. Doğan Kuban, Osmanlı Mimarisi, Yem Yayın, İstanbul 2007, p. 610.

${ }^{5}$ The first Ottoman municipal administration was established in 1857 in Pera, contemporary Beyoğlu, as the 6th Municipal Precinct. Öncel, Apartman, Galata'da, p. 13. Since Istanbul took Paris as the model of its municipality structure, the richest 6th precinct of Paris was given to Pera even though it was the first founded. Nezih Başgelen, Galata- Pera, Arkeoloji ve Sanat Yayınları, İstanbul 2003, p. 16.

6 The need to initiate new architectural styles beyond religious buildings was one of the discussions of late eighteenth- century romanticism. Lealand M. Roth and Amanda C. Roth Clark, Understanding Architecture: Its Elements, History, and Meaning, Westview Press, Boulder, 2014, p. 505.

${ }^{7}$ Ali Dost Ertuğrul, "XIX. Yüzyılda Osmanlı'da Ortaya Çıkan Farklı Yapı Tipleri”, TALID, 7/13, 2009, p. $293-4$.

${ }^{8}$ Roth and Clark, Understanding Architecture, p. 506.
} 
structure. ${ }^{9}$ When the Mayor of Paris Baron Georges-Eugène Haussmann (1809-91) rebuilt Paris in the 1850s and the 60s, the historical Nôtre Dame De Sion Cathedral went through a renovation, which caused uproar and protests because renovation made major changes on the historical cathedral. ${ }^{10}$ The European influence on the Ottoman Empire became more visible after the 1839 Tanzimat reforms, which brought centralization of power in Istanbul. The centralized Ottoman Empire initiated new rules and regulations in every aspect of life from military, economic, and political structure to reconstruction and renovation of Ottoman cities. Newly emerged European style buildings, such as industrial complexes, schools, transportation hubs, administration, culture and hospital buildings, were constructed in the traditional Ottoman architectural styl. ${ }^{11}$ Up until the European influence arrived, the Ottoman architecture did not embrace a historical understanding in its designs. Despite the rapid integration of European architectural style in buildings, European thought did not fully integrated of in the mind-set of Ottoman architects until the early twentieth century. ${ }^{12}$ Since the major architects of the Tanzimat period, especially the ones in Istanbul, were foreign architects, inevitably traditional Ottoman architecture styles faded away. The education and training of Ottoman architects was not sufficient to integrate the eclectic style in buildings. This, opened opportunities for foreign architects. ${ }^{13}$ The master mind of Ottoman Tanzimat reforms, Mustafa Reşit Pasha reported as early as 1836 that there was a need to create a legal framework to allow employment of European architects in the Ottoman Empire. In his report Mustafa Reşit Pasha mentioned that because of its wooden structures Istanbul constantly witnessed fires and this caused criticism in European newspapers. In order to avoid these fires, he suggested hiring European architects, who are experts on designing and constructing concrete or brick structures. ${ }^{14}$ Subsequently, under the influence European architects and Western educated Ottoman non-Muslim architects, Ottoman architecture went through a transformation stage in the Tanzimat period from the traditional and massive Ottoman structures to European-style designs. As these architects shaped the architecture of the buildings according to their own aesthetic understanding, they introduced a variety of architectural styles from neo-classical and empire to eclectic styles. While some art historians ${ }^{15}$ regard this transformation as negative and esthetically displeasing, it should be noted that these structures bridged the Ottoman and Western architectural styles. ${ }^{16}$ Furthermore, employment of architects outside the state structure paved the road toward development of early republican architecture in the twentieth century.

\footnotetext{
${ }^{9}$ Uğur Tuztaşı and Yusuf Civelek "Yüksek Kültürden Halk Kültürüne: Batı Mimarlığında "Ulusal Anıt” Düşüncesi ve Vernaküler Mimarinin İdealleştirilmesi”, Uluslararası Sosyal Araştırmalar Dergisi, 4/18 (2011), p. 278.

${ }^{10}$ David P. Jordan, Transforming Paris: The Life and Labors of Baron Hausmann, Free Press, New York 1995.

${ }^{11}$ Mustafa Cezar called these structures “Socially Functional Structures.” Mustafa Cezar, Sanatta Batı'ya Açıllı̧ ve Osman Hamdi Bey, Ak Yayınları, İstanbul 1971, p. 83.

${ }^{12}$ Uğur Tuztaşı and İlgi Yüce Aşkun, "Klasik Dönemden Batılılaşmaya Osmanlı Mimarlığında İdealleştirme Olgusu ve Batı Mimarlığıla Olan Mukayesesi”, Osmanlı Araștırmaları, 38 (2011), p. 215.

${ }^{13}$ Canan Hamzaoğlu, İstanbul'da Yabancı Bir Mimar William James Smith, Unpublished Master's Thesis, İstanbul Teknik Üniversitesi, İstanbul, 1996, p.2; Uğur Tanyeli states that Hassa Mimarlar Ocağı or the Ottoman Architect School produced architects as objects rather than architects with their own independent thinking. They received orders from the ruling elite and put them into practice. Uğur Tanyeli, "İstanbul'da Etnodinsel Çoğulluk ve Osmanlı Mimarlığı (15.-19. Yüzyıl): Rumlar, Ermeniler, Türkler”, in Batılllaşan İstanbul'un Rum Mimarlarl, (Yay. Haz.) Hasan Kuruyazıc1- Eva Şarlak, Zoğrafyon Lisesi Mezunları Derneği Yayını, İstanbul 2010, p. 60.

${ }^{14}$ Cengiz Can, "Tanzimat ve Mimarlık", in Osmanlı Mimarlığının 7 Yüzyılı Uluslarüstü Bir Miras, (Yay Haz.) Nur Akın, Afife Batur, Selçuk Batur, Yem Yayın, İstanbul, 1999, p. 131.

15 Prominent Turkish Art Historian Oktay Aslanapa finds these transformational structures "alien to Turkish pleasure.” Oktay Aslanapa, Türk Sanat,, Remzi Kitapevi, İstanbul 2003, p. 220; Godfrey Goodwin states that Istanbul residents reacted negatively to the attempts of foreign and local Armenian architects to change the face of Istanbul to a European city. Godfrey Goodwin, Osmanlı Mimarlı̆̆ı Tarihi, (Çev.) Müfit Günay, Kabalcı Yayınevi, İstanbul 2012, p. 546.

${ }^{16}$ Built by architect Mustafa Ağa and his Greek apprentice Simeon Kalfa between 1740 and 1755, Baroque-styled Nuriosmaniye Mosque is one of the early examples of this fusion. The largest Ottoman palace, Dolmabahçe Palace, which was built between 1843 and 1856 by the Ottoman-Armenian architects Garabet Balyan and his son Nigogayos Balyan, hosts baroque, neoclassical as well as Ottoman features.
} 


\section{A Foreigner in Istanbul: Architect William James Smith}

Ottoman-British relations were initiated in the sixteenth century with the establishment of a British embassy in Galata to facilitate the needs of British merchants settled in Istanbul. ${ }^{17}$ In 1596 Ambassador Edward Barton moved the embassy to a walled house in Pera. ${ }^{18}$ In the nineteenth century, especially after 1840, Istanbul attracted many Western European tourists, who were enthusiastic to use newly-invented commercialized photocameras. Western tourism companies arranged photo taking tours for professional and amateur photographers to Istanbul and other Middle Eastern cities. ${ }^{19}$ Travelling by sea, many British admired the beauty of Istanbul and Bosphorous and some settled in Istanbul and contributed to the diversity of city.

Prior to the construction of the Crimean Memorial Church, an Anglican church built by the British in 1868 in memory of the Crimean War (1853-56), British residents of Istanbul aimed to exhibit their existence in the city through architecture. After a series of diplomatic efforts, British architecture could join the architectural heritage of Istanbul in the 1850s. ${ }^{20}$

Like many of his compatriots William James Smith visited Istanbul after 1840; his first visit in 1842 lasted only a few months but he finally settled there in $1844 .{ }^{21}$ In the next decade he lived in Istanbul until 1853 and worked as an Ottoman palace architect during the reign of Abdulmecid I (r.1839-61) and built several structures in Istanbul. Despite a detailed work in libraries, archives and field work, no information could be gathered about the birth or death date of Smith or about his educational background. ${ }^{22}$ The Directory of British Architects 1834-1914, states nothing other than that his career was between 1830 and $1863 .^{23}$ Another source gives 1830-64 years as his active career years. ${ }^{24}$ Considering available information about his career, we can only estimate that Smith was born around 1800-1805. Smith was admitted to Royal Institute of British Architects in 1856 so it is possible that he passed away after 1856.

Relying on the documents of the Office of Works, J. M. Crook and M. H. Port state that Smith spoke French and Italian and that he was married to a woman of Spanish origin. ${ }^{25}$ In 1841

\footnotetext{
${ }^{17}$ Mustafa Cezar, XIX. Yüzyıl Beyoğlusu, Ak Yayınları, İstanbul 1999, p. 32.

${ }_{18}^{18}$ Behzat Üsdiken, Pera'dan Beyoğlu’na: 1840-1955, Akbank Kültür Sanat Kitapları, İstanbul 1999, p. 27.

${ }^{19}$ Michelle L. Woodword, "Between Orientalist Clichés and Images of Modernization: Photographic Practice in the Late Ottoman Era”, History of Photography, 27/4, 2003, pp. 363-74; Nancy Micklewright, "Turkey”, The Oxford Companion to the Photograph (ed. Robin Lenman), Oxford University Press, Oxford, 2005, p. 634.

${ }^{20}$ The first time a British architect was employed in the Ottoman Empire was in 1834, during the reign of Sultan Mahmud II (r.1808-1839). When Sultan Mahmud II decided to build a weapons factory on the shores of Golden Horn, he took the British weapon factory in London Woolwich as the model of Ottoman factory. Young and talented architect and engineer William Barlow was invited from London to design and construct the Ottoman factory. Mark Crinson, Empire Building: Orientalism and Victorian Architecture, Routledge, London 1996, p. 126; John Cladius Loudon, Architectural Magazine and Journal of Improvement in Architecture, Building and Furnishing and in the Various Arts and Trades Connected Therewith, V. I (Ed.) Longman Rees, Orme, Brown, Green \& Longman, London, 1834, p. 208.

${ }^{21}$ Kemal Kutgün Eyüpgiller, "İngiltere Elçiliği Binası ve Mimar William James Smith”, Yapı Dergisi, Sayı: 268, Mart 2004, p. 59.

${ }^{22}$ Ayșe Nasır and Nurcan Yazıcı in their dissertations and Canan Hamzaoğlu in her Master's Thesis state that they could locate neither the birth and death dates of Smith nor information on his education life. Ayşe Nasir, İstanbul Mimarlı̆̆ında Yabancı Mimarlar, Unpublished Dissertation, İstanbul Teknik Üniversitesi, İstanbul, 1991, p. 326; Hamzaoğlu, İstanbul'da Yabancı Bir Mimar, p.17; Nurcan Yazıcı, Osmanlılarda Mimarlık Kurumunun Evrimi ve Tanzimat Dönemi Mimarlık Ortamı, Unpublished Dissertation, Mimar Sinan Güzel Sanatlar Üniversitesi, İstanbul, 2007.

${ }^{23}$ Antonia Brodie, Directory of British Architects, 1834-1914: Vol. 2 (L-Z), Ed. British Architectural Library, Royal Institue of British Architects, London 2001, p. 657.

${ }^{24}$ Nicholas Savage, Gerald Beasley, Alison Shell, John Meriton Coast and Paul W. Nash, Early Printed Books 14781840, Catalogue of the British Library Early Imprints Collection, Vol. 4 (S-Z). Ed. K. G. Saur, München 2001, p. 1010.

${ }^{25}$ J.M. Crook and M.H. Port, The History of King's Works, 1782-1815, Vol.6, H.M. Stationary Office, London 1973, p. 635.
} 
when Smith was working for Commissioners of Woods and Forest ${ }^{26}$ as assistant architect under the supervision of Sir James Pennethorne, ${ }^{27}$ he was appointed as the controller architect to the reconstruction of the British Embassy in Istanbul, which was burned down in the 1831 Pera fire. ${ }^{28}$ His brief visit to Istanbul in 1842 paved the road for his second and longer venture to Istanbul from June 1844 to January $1853 .{ }^{29}$ Smith started his employment for the British Royalty in April 1830.

During his residence in Istanbul, Smith preserved his occupational and artistic ties with London. From 1837 to 1855, he participated in the annual exhibitions of Royal Academy of Arts with his architectural patterns and sketches. From 1837 to 1841 Smith submitted his works to the annual exhibit. In his first participation in 1837, Smith's work was titled "A young favourite" with registry number 408 . The next year in 1838 he participated with his "View at Abbeville" with registry number 544. In 1839 his work "Remains of the portico of Septimus Severus, Rome" appeared with registry number 167. The next year, in 1840, he showcased "(Octagon Room) Mayence" with registry number 17. In 1841 his work "Rue de St. Pierre, Rouen" with registry number 369 appeared in the exhibit as well. His lack of submission in 1842 indicates his appointment to Istanbul. According to exhibition catalog, between 1837 and 1840 Smith lived in London, 9 Upper Gloucester Street, which is in south London around Pimlico. ${ }^{30}$

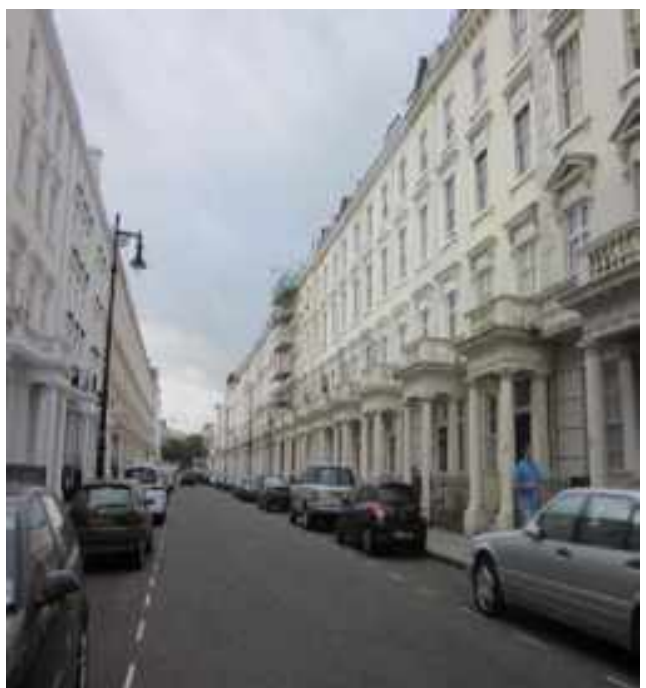

Photo 1: ${ }^{31}$ Gloucester Street where Smith lived

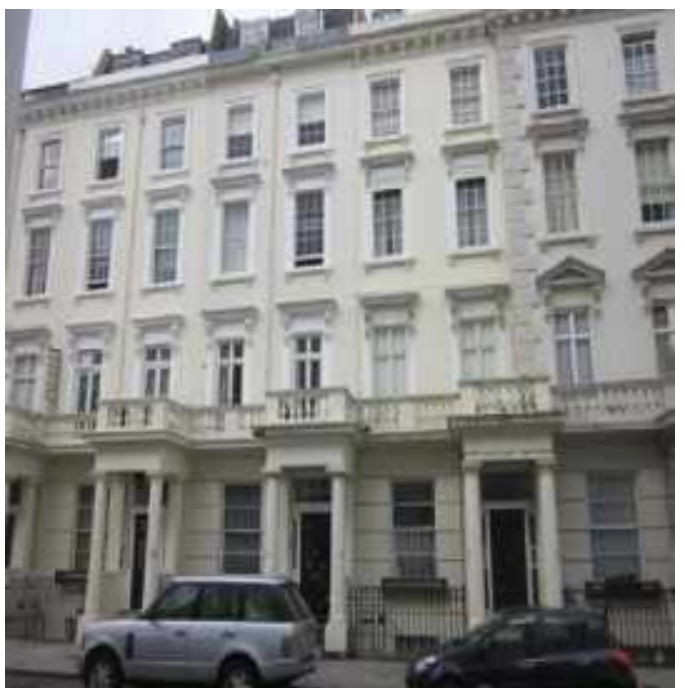

Photo 2: Smith’s home at 9 Gloucester Street

\footnotetext{
${ }^{26}$ Founded in the fourteenth century as Office of Works, which was renamed in 1832 to Commissioners of Woods and Forest (CWF), the CWF administers the properties of the British royalty. In their works, Nasır, Hamzaoğlu and Yazıc1 state that W.J. Smith worked in London in the Ministry of Environment. It appears that these authors either mistranslated or misunderstood the functions of CWF. Nasır, Istanbul Mimarlığında Yabancı Mimarlar, p. 326; Hamzaoğlu, İstanbul'da Yabancı Bir Mimar, p.17; Yazıc1, Osmanlılarda Mimarlık, p. 227. Eyüpgiller states that in 1841 Smith was working in London in an office related to Royal Properties. Eyüpgiller, Ingiltere Elçiliği, p. 59.

${ }^{27}$ Sir James Pennethorne (1801-1871) was a British architect. After his graduation from Royal Academy of Arts he continued his occupational education in the architecture office of John Nash and Augustus Charles Pugin. In 1832 he was appointed to Commissioners of Woods and Forest and worked there until 1843. In 1865 he received Royal Gold Medal for his successful career. Brodie, Directory of British Architects, 1834-1914: Vol. 2 (L-Z), p. 349.

${ }^{28}$ James Ellsworth De Kay, Sketches of Turkey in 1831 and 1832, J \& J. Harper, New York 1833, p. 84-85.

${ }^{29}$ Doğan Kuban states that William James Smith stayed in Istanbul for twelve years. But in the next page Kuban writes that Smith arrived Istanbul in 1841 for the reconstruction of British Embassy, which lasted ten years, and stayed there throughout the project. According to Kuban's second statement, Smith should have stayed in Istanbul for ten years. Kuban, Osmanlı Mimarisi, p. 610-611; Crinson, Empire Building, p. 126.

${ }^{30}$ Algernon Graves, The Royal Academy of Arts: A Complete Dictionary of Contributors and Their Work from Its Foundation in 1769 to 1904, Vol 7, Graves \& Bell, London 1905, p. 195.

${ }^{31}$ All photos in this article have been taken by Esma İüs unless otherwise indicated.
} 
In 1843 his works appeared in the exhibit; "The Ambassador's palace now erecting at Constantinople" and "Cavalry Hospital at Constantinople." These works were his first sketches from Istanbul and included his first visions of the orient and built a cultural bridge between the Anglo-Saxon world and the Ottoman Empire. The exhibit catalog indicates an address change in 1841 from 9 Upper Gloucester Street to 7 Whitehall Yard. According to a London guide book dated 1865, 7 Whitehall Yard was the address of British Foreign Office. ${ }^{32}$ Because he was relocated to Istanbul for the embassy building reconstruction, his mail was possibly transferred by the Foreign Office. It appears that Smith was busy with his work in Istanbul and he could not submit any work to the annual exhibit until 1851. His work in 1851 called "Medical Hall, Constantinople" with the registry number 290. In 1851 he either briefly visited London or mailed his work to the exhibit. His last work "Hospital for French Troops Near Pera, Constantinople" appeared in the exhibit was in 1855 with the registry number 1125.

In the 1851 and 1855 exhibition listings Smith's address is listed as 40 Fitzroy Square in Warren Street in London, ${ }^{33}$ where he resided between 1853 and 1855 after he left Istanbul.

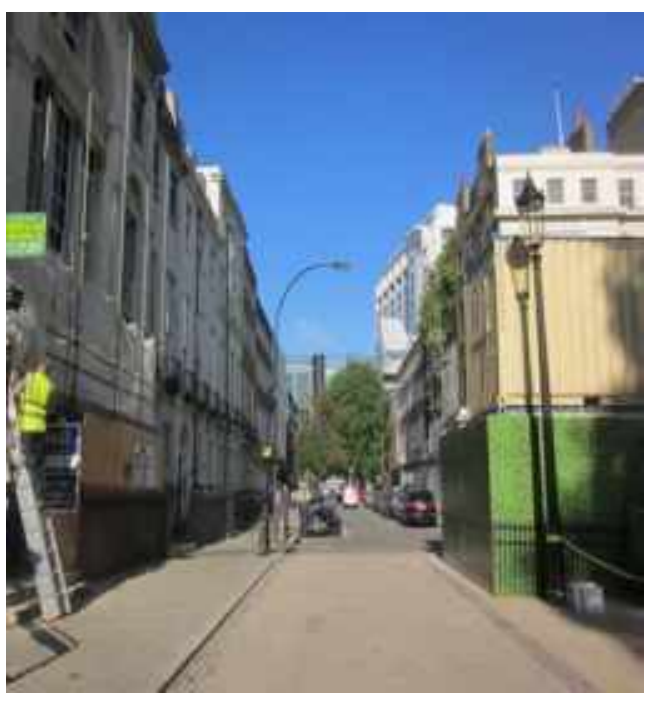

Photo 3: General View, Fitzroy Square, Warren Street

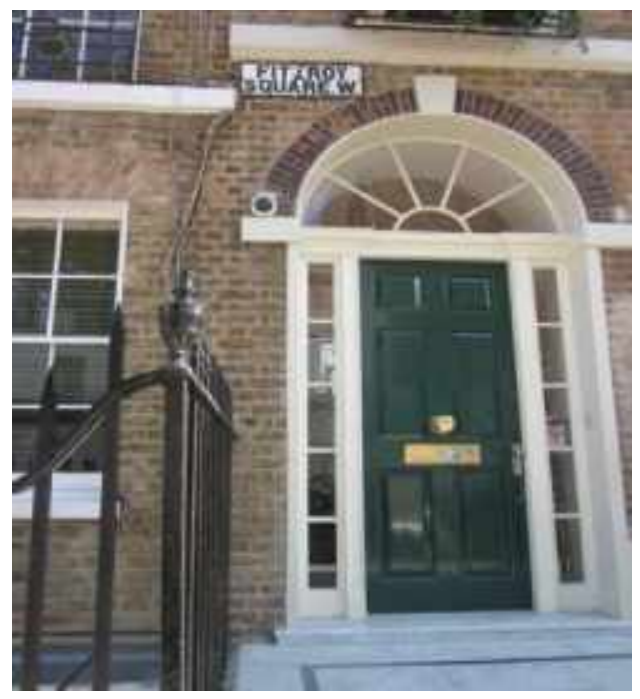

Photo 4: Warren Street Sign

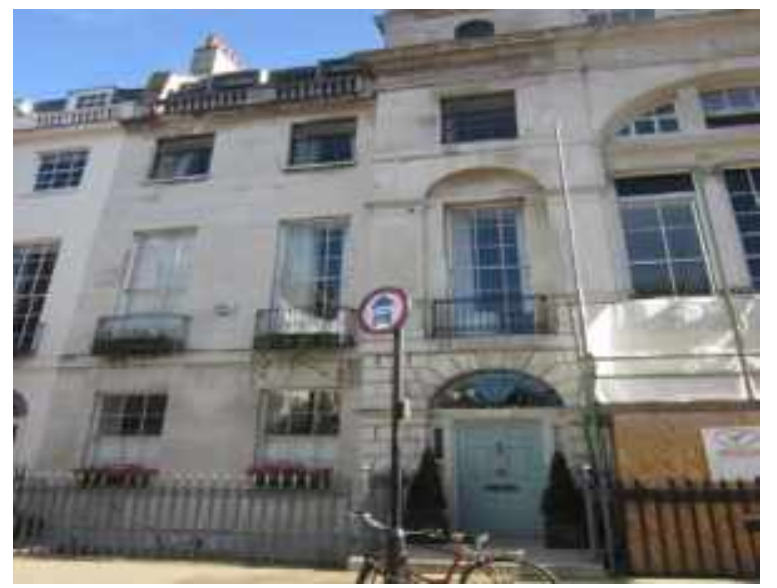

Photo 5: ${ }^{34}$ William James Smith's Residence at Fitzroy Square Warren Street

\footnotetext{
${ }^{32}$ Robert Hardwicke, Hardwicke's Shilling Handy-Book of London, S. Hardwicke, London 1865, p. 13.

${ }^{33}$ A short biography of Smith given in Directory of British Architects,includes this address. Brodie, Directory of British Architects, 1834-1914: Vol. 2 (L-Z), p. 657.
} 
The reconstruction of British Embassy building that was destroyed in 1831 started in1842 but it could not be completed until 1853. British scholars Crook and Port present three reasons for this delay: 1- The distance between the Ottoman Empire and Great Britain, which took three weeks through by sea, 2- Slow communication lines, 3- Challenges of construction in a despotic country. ${ }^{35}$ Smith travelled to Istanbul in 1842 and did his feasibility study on the site and returned to London in October 1842 to finish his project. After the British Foreign Office had approved his project in April, Smith arrived in Istanbul in June 1843 to launch the construction. Smith received monthly payments of $£ 700$ British pounds as the Chief Architect of the embassy building construction. A brief dispute between the Ottoman and the British governments over the land for the proposed embassy building put the construction on hold for a while but the work resumed in 1844. By the time the roof of building was done in November 1846, Smith had a serious illness and had to take four months of treatment in Italy. ${ }^{36} \mathrm{He}$ returned to Istanbul in early 1847 and worked on the details of the construction.

An Ottoman document dated April 24, 1853, states that, Smith, the architect/apprentice of Mecidiye Kışlası/barrack received 4,000 Ottoman kuruş monthly ${ }^{37}$ since January 1846 but he visited the construction site once or twice a month and an inquiry revealed that he was preparing to return Great Britain. Therefore, it was suggested that his employment and payment be terminated at the end of April 1853 terminated because of his decision to return. ${ }^{38}$ Two years earlier in 1851 another correspondence occurred in the Ottoman bureaucracy to terminate Smith's payments but apparently payment continued. ${ }^{39}$

A request from the Ottoman foreign ministry to reward Smith for his hospital plan was initially rejected on February 25, 1846 because Smith's planned hospital was not constructed. ${ }^{40}$ Nevertheless three months later on May 6, Smith was honored with a sixth degree Ottoman award (kut'a nişan). ${ }^{41}$ British ambassador Stratford Canning found this reward lower than the one granted to the Fossati brothers, the architects of the Russian embassy. Canning's action produced results and the degree of Smith's award was raised on May $10{ }^{42}$ Feryal İrez and Hüsamettin Aksu posit that Smith drafted the hospital plan in 1845 but the hospital was never constructed. Nevertheless, Smith still requested an award for his work and the award was eventually granted. ${ }^{43}$ Mustafa Cezar points out that the plan Smith prepared was for Gümüşssuyu Military Hospital, which was completed within two years 1847-1849 and Sultan Abdülmecid joined the opening ceremony. ${ }^{44}$

\footnotetext{
34 The field study to locate Smith's residence in Warren Street revealed that the numbering of residences along the street was changed. According to information provided by the current residents of Warren Street, the numbers of apartments at the beginning of the street remained the same but the apartment numbers from the middle of the street were renumbered. The apartment with the current number 8 was numbered 40 in the old system.

${ }^{35}$ Crook and Port, The History of King's Works, p. 635.

${ }^{36}$ Eyüpgiller, İngiltere Elçiliği Binası, p. 59.

${ }^{37}$ During the reign of Abdulmecid I (1839-61) $1 £$ British pound was equal to 110 Mecidiye kuruş. Accordingly, the monthly payment William James Smith received from the Ottoman Empire was $36 £$ British pounds. Compared to $700 £$ pounds Smith received from the British government $36 £$ pounds was a very limited amount but given the cost of living in Istanbul it was a decent payment. M. Özgür Yanardăg, "19. Yüzyıl Osmanlı Devleti Para Düzeni: Kâğıt Para Kullanımına Geçiş Aşamalarının İktisadi Analizi”, Uluslararası Sosyal Araştırmalar Dergisi, 8/36 (2015), p. 927.

${ }^{38}$ Başbakanlık Osmanlı Arşivi (BOA), Irade-i Hariciye (İ.HAR), Dosya No: 98, Gömlek No: 4772, Tarih: 15 Receb 1269 (24 April 1853).

${ }^{39}$ Yazıcı, Osmanlilarda Mimarlık, p. 227.

${ }^{40}$ BOA, İrade-i Hariciye (İ.HAR), Dosya No: 33, Gömlek No: 1527, Tarih: 28 Safer 1262 (25 February 1846).

${ }^{41}$ BOA, Mühimme Kalemi Belgeleri (A.DVN.MHM), Dosya No: 2A, Gömlek No: 73, Tarih: 10 Cemazilyelahir 1262 (6 May 1846).

42 BOA, Irade-i Hariciye (İ.HAR), Dosya No: 35, Gömlek No: 1605, Tarih: 14 Cemaziyelevvel 1262 (10 May 1846).

${ }^{43}$ Feryal İrez ve Hüsamettin Aksu, Boğaziçi Sefarethaneleri, Yapı Kredi Yayınları, İstanbul 1992, p. 61-62.

${ }^{44}$ Mustafa Cezar, Osmanlı Başkenti İstanbul, Erol Kerim Aksoy Vakfi Yayınları, İstanbul 2002, p. 498.
} 
During his residence in Istanbul, William James Smith had several opportunities to meet Sultan Abdülmecid. One of these occasions, on July 5, 1847, was for the ground breaking ceremony of Naum Theater. Smith drafted the plan for the theater for free while Sultan Abdülmecid provided funding for the construction. Along with Sultan Abdülmecid and Smith, the theater owner Michel Naum, musician Guiseppe Donizetto, ${ }^{45}$ and Levanten banker Antoine Alleon, were among the prominent members of the Istanbul elite in the event. During the event Smith conversed with the sultan and with the encouragement of this conversation he built a small replica of the theater and sent it to sultan via banker Alleon. ${ }^{46}$ The second time Smith encountered the sultan on the construction site of Naum Theater. Sultan Abdülmecid visited the site after a Friday prayer and Smith informed the sultan about the process of consruction. ${ }^{47}$ Smith was also the architect of the Tophane Pavilion. During the opening of pavilion, Sultan Abdülmecid praised the work of Smith. With his high quality projects and constructions Smith received positive praise on several occasions. Compared to other architects, Smith's stay in Istanbul was limited. Shortly, after he returned to Great Britain in 1853, he initiated an application to join the Royal Institute of British Architects on November 14, 1855 and his membership was approved on January $14,1856 .^{48}$

\section{William James Smith in Travel Books}

Two western travelers mentioned William James Smith in their travel books in the midnineteenth century. The fact that he was mentioned indicates his significance in the Ottoman bureaucracy and social life. Scottish traveller Charles MacFarlane questioned Smith's actions in Istanbul and seriously targeted him. MacFarlane blamed Smith for deliberately delaying completion of the British Embassy because Smith was receiving a big salary from the British government and he did not wish to end the flow of money. MacFarlane added that despite all the good opportunities provided to him Smith did not have any fame as an architect in London. ${ }^{49}$ Moreover, MacFarlane stated that Smith did not visit the construction site and allowed Armenian subcontractors do his work, picked up other private projects to earn money and he was in a very close business relationship with an unreliable Armenian merchant Migraditch Samanji Oglou. MacFarlane claimed Samanji Oglou sold expensive tiles to the embassy construction and caused financial damage to the British government. ${ }^{50}$

Another British traveler, Albert Smith, visited Istanbul in the same time period. In his work Albert Smith mentioned about architect Smith more positively compared to MacFarlane. The palace of our Ambassador was burnt down in 1831; and a new one is nearly completed, under the able direction of Mr. Smith - it is needless to say, an English architect - to whose taste and experience Pera and the Bosphorus will soon be indebted for most of their finest buildings. ${ }^{51}$

Albert Smith also visited Smith's house in Pera ${ }^{52}$ and noted that the architect's house was designed in a British style. This traveller also mentioned the tobacco box with diamond

\footnotetext{
${ }^{45}$ Italian musician Guisseppe Donizetti (1788-1856) was invited to the Ottoman Empire by Sultan Mahmud II to restructure Mûsikâ-i Hümâyûn or the Ottoman royal orchestra. Donizetti worked twenty eight years for the Ottoman Empire and he was granted a Pasha title for his service. Stephen Vernoit, "Western Asia and Arab Lands", in History of Humanity, The Nineteenth Century, Volume VI (Ed.) Peter Mathias, Nikloai Todorov, Routledge, London 2005, p. 229.

${ }^{46}$ Emre Arac1, Naum Tiyatrosu: 19. Yüzyll İstanbulu'nun İtalyan Operasl, Yap1 Kredi Yay., İstanbul 2010, p. 109.

${ }^{47}$ Süha Umur, “Abdülmecit, Opera ve Dolmabahçe Sarayı Tiyatrosu”, Milli Saraylar Dergisi, 1987/1, p. 50.

${ }^{48}$ Hamzaoğlu, İstanbul'da Yabancı Bir Mimar, p. 18.

${ }^{49}$ Lack of clear information about Smith’s life in G. Britain supports Charles MacFarlane's argument that Smith was not a well-known architect in the nineteenth-century British architecture.

${ }^{50}$ Charles MacFarlane, Turkey and Its Destiny: The Result of Journeys Made in 1847 and 1848 to Examine into the State of that Country, Lea and Blanchard, Philadelphia 1850, p. 227.

${ }^{51}$ Albert Smith, A Month at Constantinople, David Bogue, London 1850, p. 181.

${ }^{52}$ Relying on an Ottoman document Nurcan Yazıc1 posits that William James Smith was granted a right to home ownership in the Ottoman Empire and the Ottoman government provided him some money to purchase a house in
} 
decorations that Smith had received from Sultan Abdülmecid. ${ }^{53}$ Sultan Abdülmecid gave these diamond-decorated tobacco boxes to Guisseppe Donizetti and William James Smith on the opening day of Naum Theatre after the first show. The box was valued 20,000 kuruş at that time. $^{54}$

\section{William James Smith: an Architectural Historian}

Beyond his active architect career, in 1831 William James Smith published a book titled A Synopsis of the Origin and Progress of Architecture. ${ }^{55}$ This book was the revised version of an earlier book, A Synopsis of Architecture for the Information of the Student and Amateur, written by architect Charles Edward Ernest Papendiek in $1826 .{ }^{56}$ Smith and Papendiek worked together at Commissioners of Woods and Forest in 1830 and 1831 and probably Smith familiarized himself with Papendiek and his book during this time. ${ }^{57}$

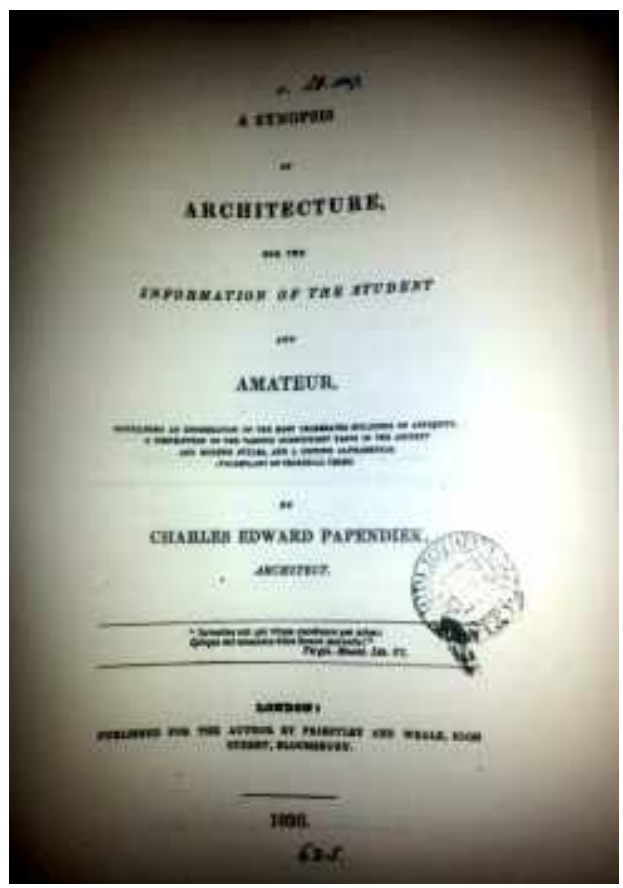

Photo 6: Interior cover of Papendiek’s book

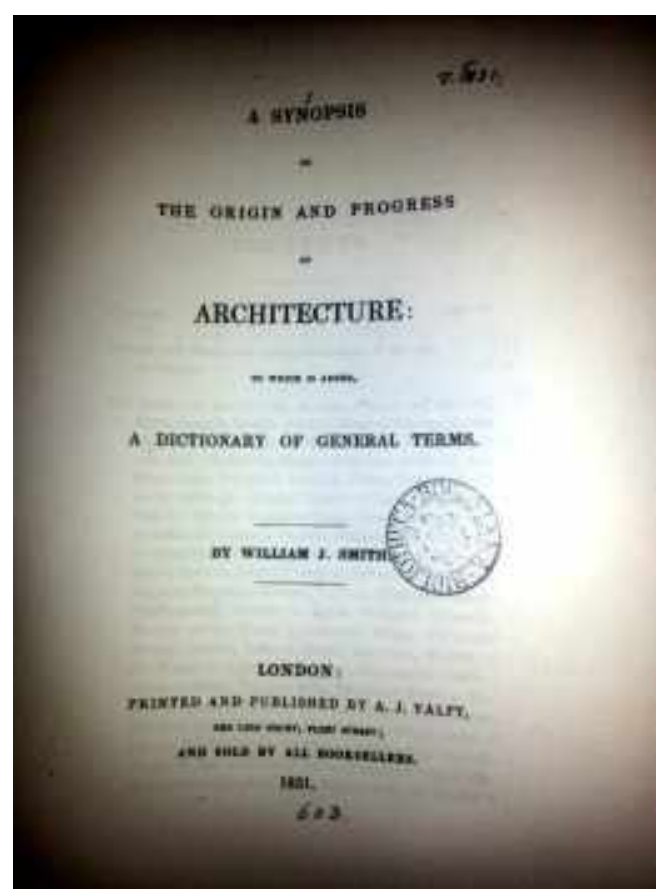

Photo 7: Interior cover of Smith’s book

William James Smith is a very popular name in Great Britain. This fact requires any researcher to verify several variables to confirm whether or not the author of the book, who was named William J. Smith, was indeed architect William James Smith. William James Smith was listed on the $1010^{\text {th }}$ and the $1011^{\text {th }}$ pages of Early Printed Books 1478-1840 with details. The

Istanbul. Yazıc1, Osmanlılarda Mimarlı, p.235; Mustafa Cezar writes that Smith was granted 200,000 Ottoman kuruş to buy a house, while architect Fossati was not allowed to purchase a house at the entrance of Dörtyol. [This place was most likely Dörtyol at Pera Asmalımescit.] Cezar, Osmanlı Başkenti İstanbul, p. 129.

${ }^{53}$ Smith, A Month at Constantinople, p. 188-89.

${ }^{54}$ Arac1, Naum Tiyatrosu, p. 129.

${ }^{55}$ A copy of the original 1831 edition is preserved in the library of Royal Institute of British Architects with an inventory number 3084.

${ }^{56}$ Charles Edward Ernest Papendiek, A Synopsis of Architecture, for the Information of the Student and Amateur, Priestley and Weale, London 1826. British architect Charles Edward Ernest Papendiek (1801-1835) graduated from the Royal College of Arts and he was a student of Sir John Soane between 1818 and 1824. He participated the annual exhibitions of the Royal Academy of Arts from 1823 to 1831. Nicholas Savage, Nicholas Savage, Gerald Beasley, Alison Shell, John Meriton Coast and Paul W. Nash Early Printed Books 1478-1840, Catalogue of the British Library Early Imprints Collection, V. 3. (M-R), Ed. K. G. Saur, München 2001, p. 1385.

${ }^{57}$ Savage, Early Printed Books 1478-1840, V. 3. (M-R), p. 1011. 
biography of Smith in this catalog includes information that architect Smith designed the British Embassy building in Constantinople and several other buildings in the same complex. It also mentions Smith's employment at Commissioners of Woods and Forest. The publication date of the book (1831) matches the chronology of Smith's biography. All these facts exhibit that William James Smith was the author of A Synopsis of the Origin and Progress of Architecture.

The book has 133 pages and 11 plates with sketches. The earlier version authored by Papendiek had 122 pages and 11 plates. The two books were almost identical in terms of their title and content. Both authors start the beginning of architectural history from 2247 BS, when the Tower of Baber was built, and bring it to the Gothic period. Then both examine religious and civilian architecture examples from Asia, Africa and Europe. They also cover ancient Anatolian architecture; Smith covers more ancient temples than Papendiek. ${ }^{58}$ Some sections of Smith's book between the pages of 3 and 68 were copied word by word from the book of Pappendiek's, including a dictionary of general terms,. Also, two of the 11 plates in Smith's book were used in Papendiek's book but Smith did not credit Pappendiek, instead he initialed plates with W.S. Smith. ${ }^{59}$ In his book Smith included additional analysis about historical British Cathedrals and the significance of their construction in the history of architecture between the pages of 69 and 99. Moreover, Smith added a dictionary of general architecture terms in his book, included more samples of structures, and made Papendiek's text clearer.

\section{William James Smith's Architectural Works in Istanbul ${ }^{60}$}

\section{British Embassy Building}

The British government had had an embassy building in Galata since $1596 .{ }^{61}$ After the embassy building was burned down in 1831 Pera fire, the embassy was relocated to Tarabya but Tarabya was at the periphery of the city and this caused inconvenience. Thus, the British government decided to construct a new embassy building in Pera in 1841. While the majority of sources indicate that William James Smith was the sole architect of British Embassy building in Pera, Burcu Özgüven adds that Charles Barry was another architect who worked on the embassy building. ${ }^{62}$ The embassy building plans, which are located in the British National Archives, has William James Smith's name on them. No embassy building plan was found with Charles Barry's name. The two traveller books mentioned earlier from the mid-nineteenth century also stated that Smith was the architect of embassy building. Rumors of corruption on the construction project triggered an audit and the architect of British Houses of Parliament, Charles Barry, audited the project. Because of this audit, some authors incorrectly credit Barry as the architect of embassy building. ${ }^{63}$ While he was working for the Commissioners of Woods and Forest (CWF) in London, Smith initially visited the site of embassy building in Istanbul in 1842. ${ }^{64}$ After he returned to London in October 1842, Smith designed a larger embassy building

\footnotetext{
${ }^{58}$ Papendiek's book covers the Mausoleum of Halikarnassos and Ephesus Temple of Artemis, from the ancient Anatolian architecture. Other than the Mausoleum of Halikarnassos and Ephesus Temple of Artemis, Smith covers Temple of Apollon in Didim, Turkey, Temple of Bacchus in Lebanon, and Laodikeia Temple in western Turkey.

${ }^{59}$ The first plate was the "Plan of the Greek Agora or Forum” the second one was "Plan of a Greek House.” In the "Plan of the Greek Agora or Forum" Papendiek indicated sections with letters, while Smith used numbers. In the "Plan of a Greek House" both architects used letters.

${ }^{60}$ William J. Smith's works in Istanbul require detailed analysis in terms of their achitectural value but the skope of evaluation in this section will be limited to building style of these structures and their short history.

${ }^{61}$ Said N. Duhani, Eski Inssanlar, Eski Evler: 19. Yüzyılın Sonunda Beyoğlu'nun Sosyal Topoğrafyası, Translated by Ahmet Parman, Türkiye Otomobil ve Turing Kurumu, İstanbul 1984, p. 42.

${ }^{62}$ Burcu Özgüven, "İngiltere Elçiliği Binası", Dünden Bugüne İstanbul Ansiklopedisi, C. IV., Kültür Bakanlığı ve Tarih Vakfi Yurt Yayınları Ortak Yayını, İstanbul 1994, p. 175.

${ }^{63}$ Crinson, Empire Building, p. 126.

${ }^{64}$ Crinson, Empire Building, p. 126.
} 
than the one that had burned down; the building had a rectangular shape with a central courtyard. ${ }^{65}$

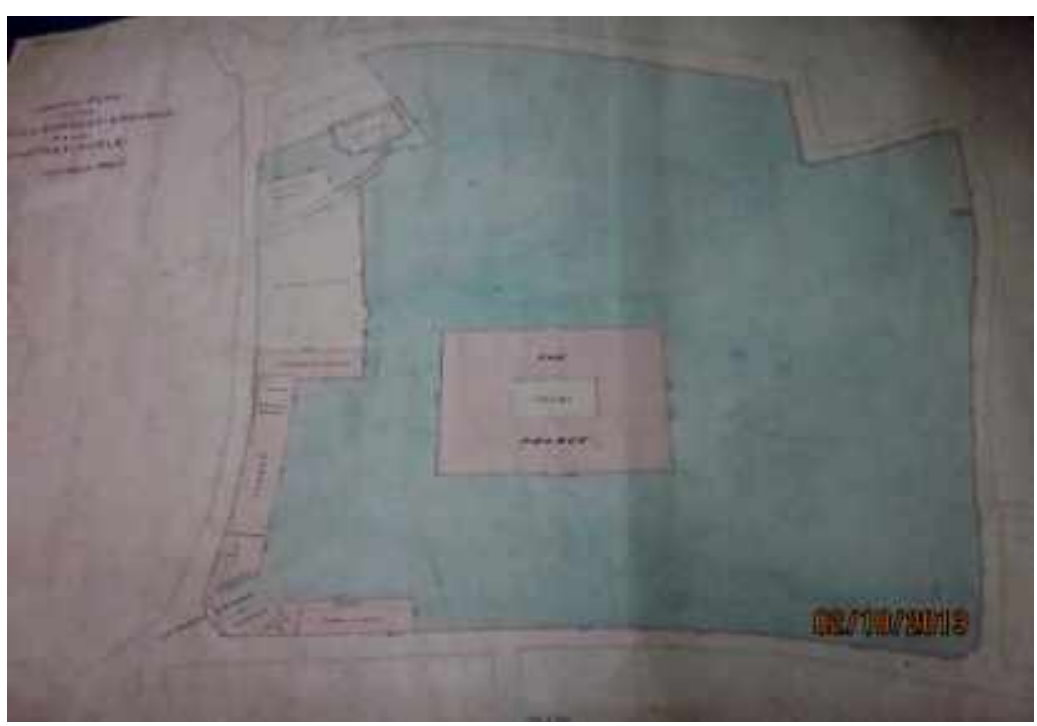

Photo 8: William James Smith’s General Plan of the British Embassy Building in Istanbul. ${ }^{66}$

The construction of British Embassy building was mostly completed by 1851 but additional buildings in the complex were added in 1853. An examination of an 1852 draft of the plan plan (photo 8 above), the main embassy building has a rectangular shape with a courtyard in the middle. Other service buildings in the complex, including a church, servants' quarter, and a stable, horse cart garage, and laundry room were lined up on the western side of main building.
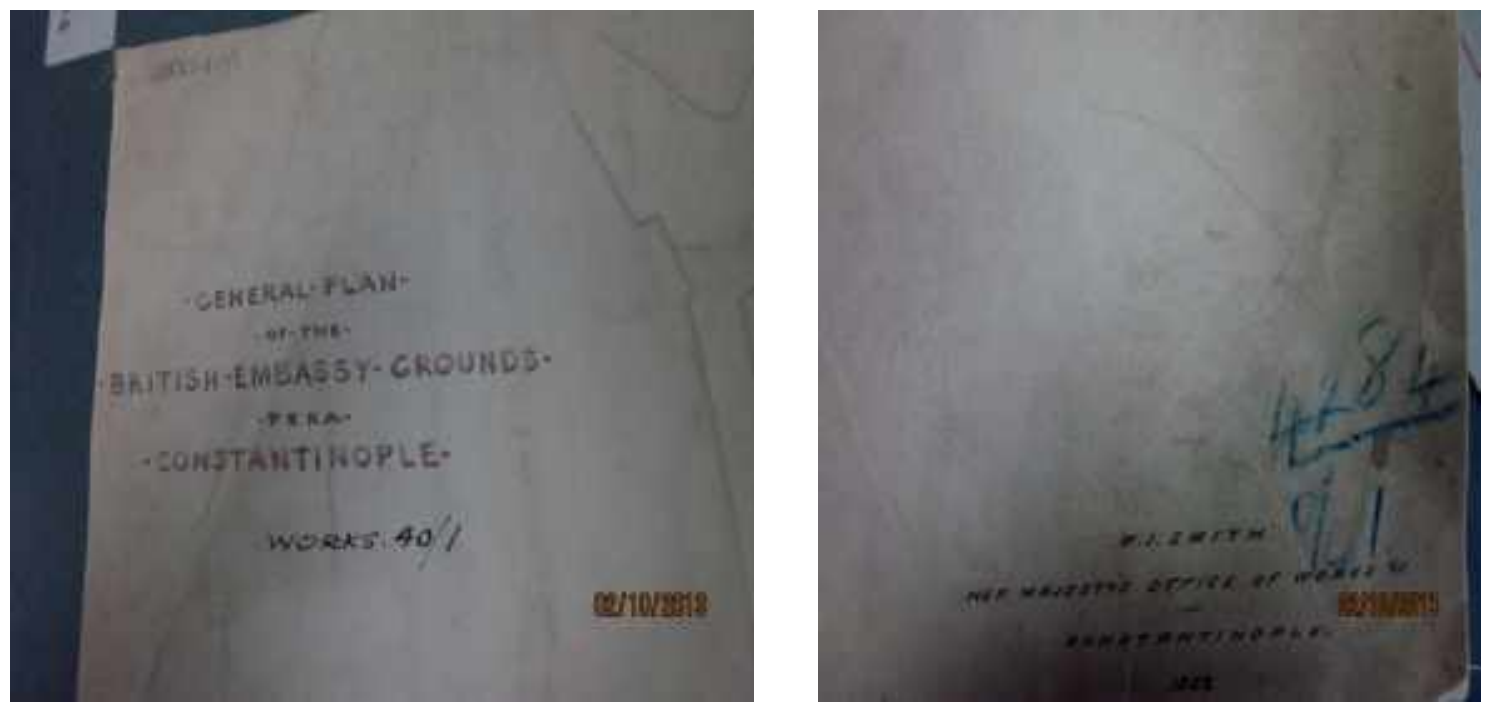

Photo 9: William James Smith’s General Plan of the British Embassy Building in Istanbul. William James Smith’s name is visible on the right page lower part along with date, $1852 .{ }^{67}$

\footnotetext{
${ }^{65}$ Eyüpgiller, İngiliz Elçiliği Binası, p. 59.

${ }^{66}$ London National Archives, Office of Works 40-1.

${ }^{67}$ London National Archives, Office of Works Works 40-1.
} 


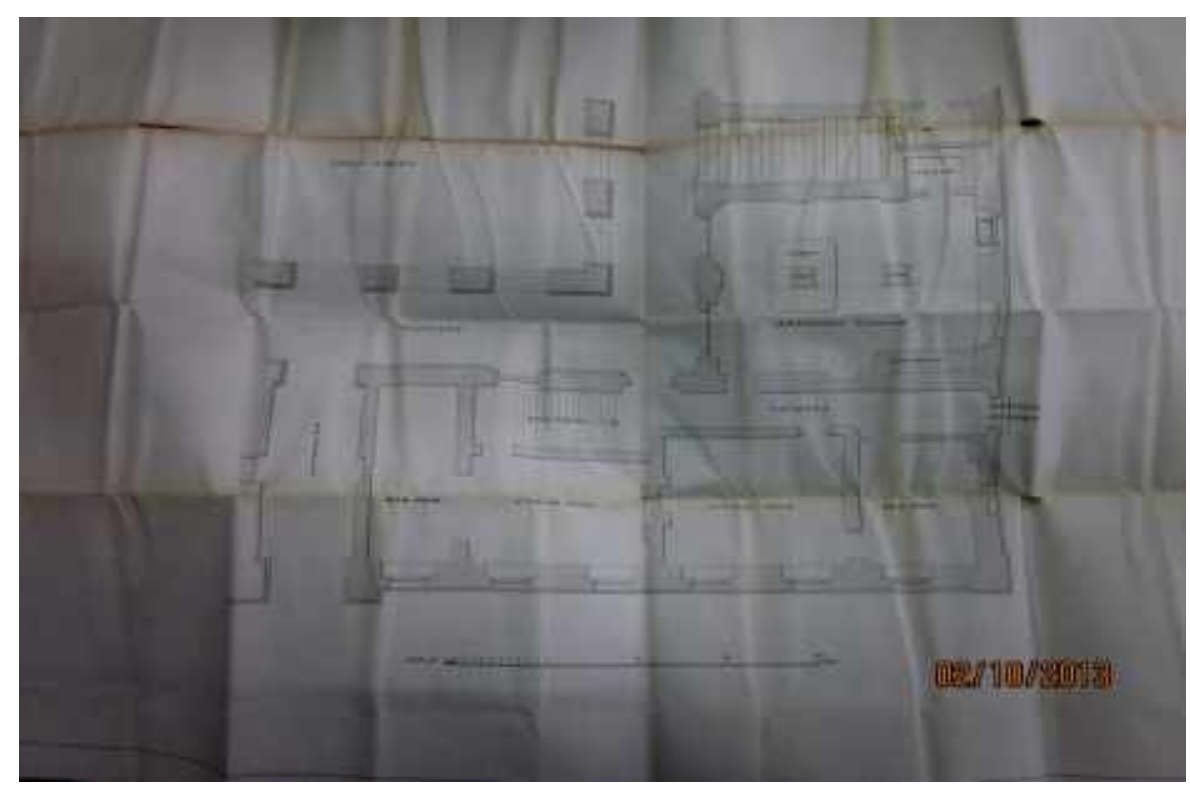

Photo 10: British Embassy Residence Plan. ${ }^{68}$

The British Embassy Residence Plan(photo 10) has the signature of William James Smith. The residence has two living rooms, two bedrooms, a kitchen with a large table and hallways leading to stables. The walls were designed to be quite thick.

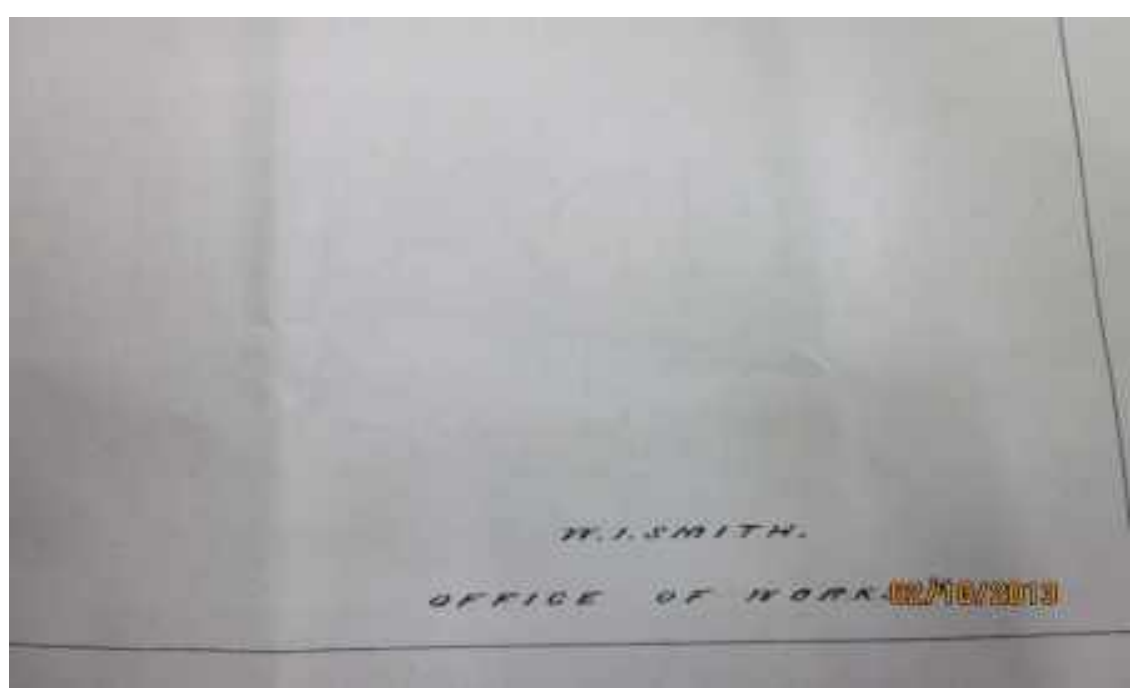

Photo 11: British Embassy Residence Plan has William James Smith on right lower corner. ${ }^{69}$

\footnotetext{
${ }^{68}$ London National Archives, Office of Works Works 10-5.

${ }^{69}$ London National Archives, Office of Works Works 10-5.
} 


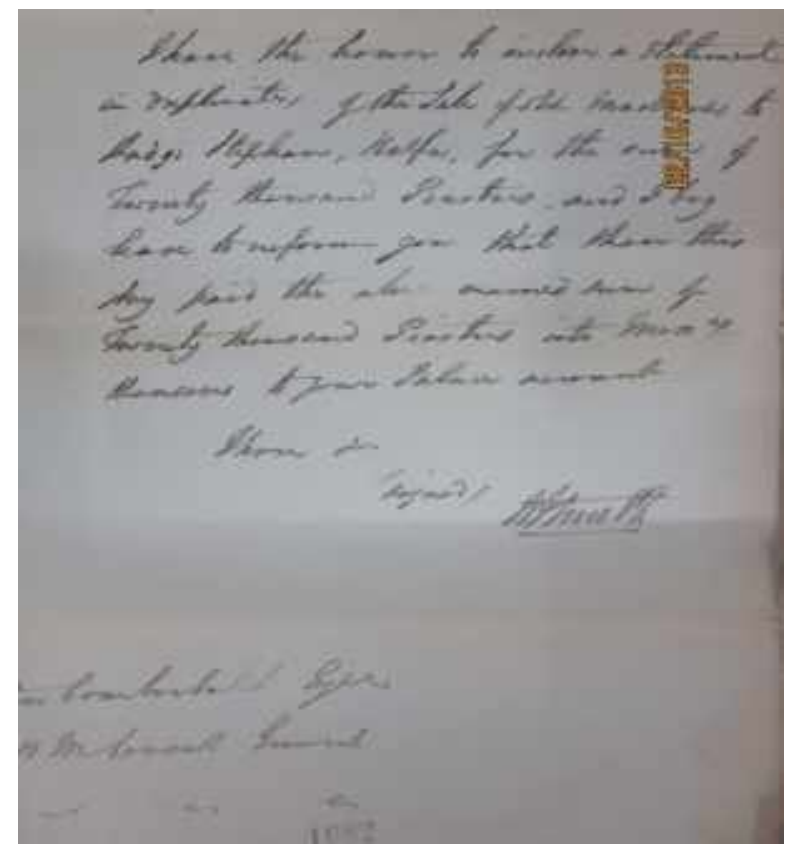

Photo 12: William James Smith’s handwriting and signature. ${ }^{70}$

During the construction of embassy building Smith regularly wrote hand-written reports about the progress of construction, daily work on the site, unexpected setbacks and expenses and mailed these reports to London. ${ }^{71}$

\section{Tophane-i Amire Hospital (Gümüşsuyu Military Hospital)}

William James Smith designed and built this neoclassical hospital between 1847 and $1849 .{ }^{72}$ High ceelings and wide hallways and windows allow sun light in all sides of the hospital. $^{73}$

\section{Mecidiye Kışlası (Taşkışla), Mecidiye or Stone Barracks}

As part of reformation in the Tanzimat period, Western-style military barracks were built around Istanbul. Mecidiye Kışlası or Taşkışla was one of these barracks built in this period. The construction initially started in 1847 as a medical school building out of stone that was to replace the former wooden medical school building in Galatasaray. Years later in 1849 it was decided to turn the school building to a military barrack. The September 14, 1848 issue of Journal de Constantinople stated that one and a half year earlier the government ordered the designs of the building from reputable architect William James Smith. We do not have any clear information about the year when construction was completed. During the Crimean War, the building was used as a hospital for French soldiers but was abandoned after the war. The

\footnotetext{
${ }^{70}$ London National Archives, Office of Works Works 10-5.

${ }^{71}$ These lenghty and detailed reports from the National Archives will be examined in another work.

72 Another source gives 1846 as the construction launch day. Merve Pabuçcu, "Osmanlı Devleti'nde Askerî Hastaneler (1876-1908)”, Cappadocia Journal of Social Sciences, 3 (2014), p. 91; In 1845 William James Smith was commissioned to design a hospital but his plan was not liked. It is unclear whether or not the Gümüsssuyu Military Hospital plan was the revised version of this commissioned project. Yazıc1, Osmanlılarda Mimarlık, p.230; Cezar, XIX. Yüzyll Beyoğlusu, 1991, p. 498.

${ }^{73}$ Pabuçcu, Osmanlı Devleti'nde Askerî Hastaneler, p. 91.
} 
building was renovated in 1861 by a special order of Sultan Abdülaziz (r.1861-76) and used for military purposes. ${ }^{74}$

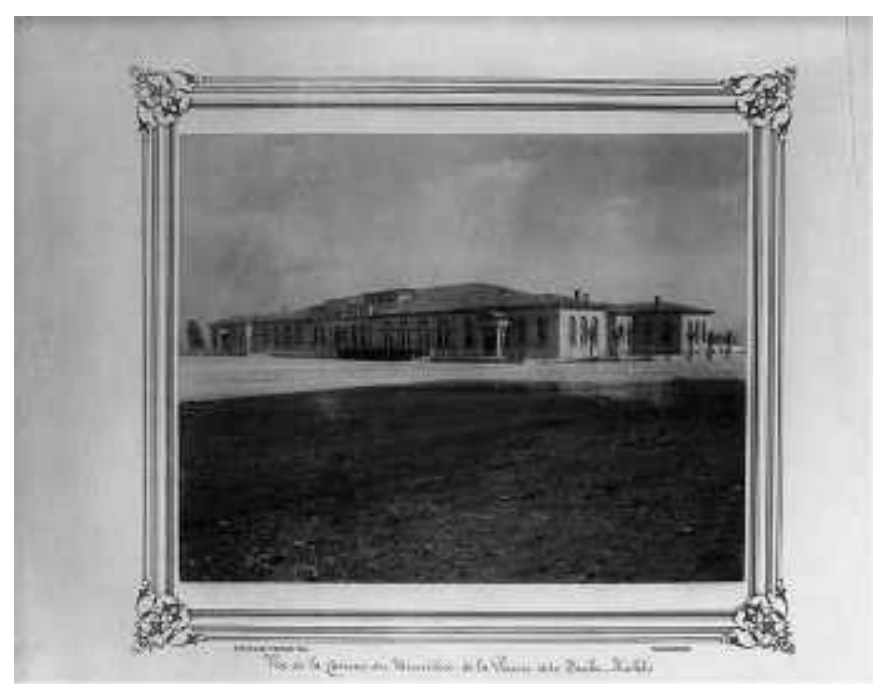

Photo 13: Mecidiye Kışlası (Taşkışla), between 1880 and $1893 .{ }^{75}$

Taşkışla has three floors with a rectangular plan and a central courtyard, which matches other military barracks of the nineteenth century. The neoclassic style dominates all sides of the building. In order to create a neoclassic look on the front side, the architect used ionic columns on the first floor, cosmopolitan columns on the second floor, and Toscana columns on the third floor. $^{76}$

\section{Selimiye Kışlası or Barracks, North Side Renovation}

Selimiye Kışlası or the barracks were built during the reign of Sultan Selim III (17891807) on the Asian side of Istanbul, Üsküdar, on land formerly occupied by the demolished Kavak Palace. A ground breaking ceremony was held with the participation of the sultan in 1800 and it was completed around $1805-06 .{ }^{77}$ The northern side of the barracks was damaged in the 1847 fire and Smith was hired in 1848 to repair the damaged section. ${ }^{78}$

\footnotetext{
${ }^{74}$ Afife Batur, “Taşkışla İçin Küçük Bir Tarih”, Prof. Doğan Kuban'a Armă̆an, (Yay Haz.) Zeynep Ahunbay, Deniz Mazlum, Kutgün Eyüpgiller, Eren Yayıncılık, İstanbul 1996, p. 118.

75 "View of the Taşkışla Barracks of the Ministry of War", Library of Congress, Abdul Hamid II Collection, LCUSZ62-81696.

${ }^{76}$ Afife Batur, "Taşkışla”, Dünden Bugüne İstanbul Ansiklopedisi, C. VII. Kültür Bakanlığı ve Tarih Vakfi Yurt Yayınları Ortak Yayını, İstanbul 1994, p.222.

${ }^{77}$ Kuban, Osmanlı Mimarlığ 1 , p.554.

${ }^{78}$ Nasır, İstanbul Mimarlığında Yabancı Mimarlar, p.52.
} 


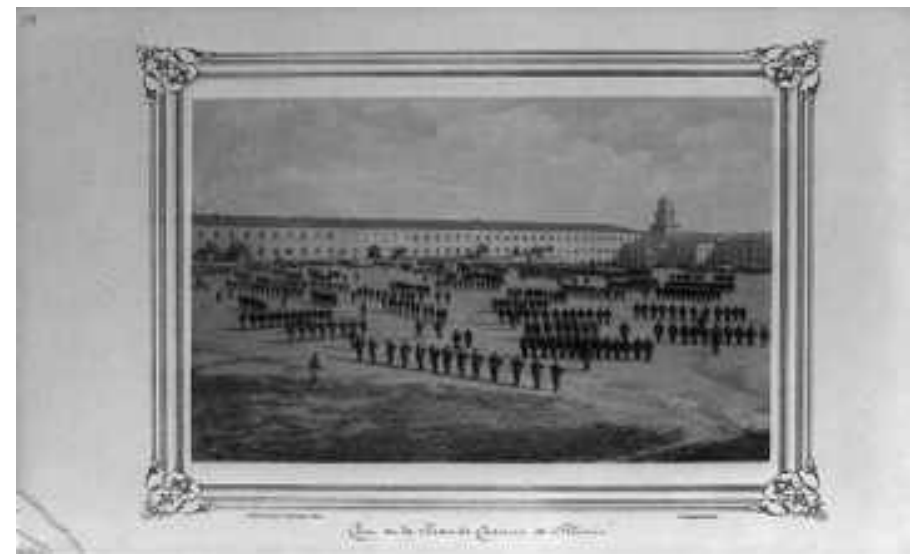

Photo 14: Ottoman soldiers training in Selimiye Barracks Courtyard, between 1880 and $1893 .^{79}$

\section{Dolmabahçe Palace Winter Garden and Alay Köșkü, the Procession Kiosk}

These structures in Dolmabahçe Palace were done in 1853 and 1854 shortly before Smith returned to London. ${ }^{80}$ The rectangular shaped Winter Garden was decorated with in British taste and had a crystal fountain in the center. ${ }^{81}$ Alay Köşkü or the Procession Kiosk was designed for Sultan Abdülmecid to view parades and people. In order to expand the view, the pavilion was designed outward from the palace walls. The neoclassic front rises up above Corintian columns and the front side facing the street is the most decorated part of the kiosk.

\section{Kuledibi Structures}

William James Smith also designed the British Seamen’s Hospital and a prison a prison at the request of the British Embassy that would be part of the hospital for the embassy in Galata, Kuledibi. The hospital was funded by the British government and opened in $1855 .^{82} \mathrm{Big}$ section of the hospital was demolished in 1901 and rebuilt in 1904. After it was transferred to Turkish Red Crescent in 1924, it has been used as a hospital. ${ }^{83}$

\section{Tophane Kasri, Tophane Imperial Pavilion}

Tophane Kasr1 was another Ottoman structure which William James Smith built as an architect. It was built in 1851 under the supervision of Tophane Müşir (field marshal) Halil Paşa and it was the first pavilion that Sultan Abdülmecid had built. ${ }^{84}$ Built at the port of Tophane, the pavilion was designed as the first spot to welcome and briefly host foreign statesmen arriving Istanbul through by sea. Sultan Abdülmecid attended the opening ceremony and expressed his pleasure of the building and praised Smith for his good work. ${ }^{85}$

\footnotetext{
79 “The courtyard of the great Selimiye Barracks,” Library of Congress, Abdul Hamid II Collection, LC-USZ6282335.

${ }^{80}$ Yazıc1, Osmanlılarda Mimarlık, p. 233.

${ }^{81}$ Hamzaoğlu, İstanbul'da Yabancı Bir Mimar, p. 61.

${ }^{82}$ Nuran Yıldırım, A Tour of the History of Medicine in Istanbul Taksim- Beyoğlu- Üsküdar, Turkish Society of Clinical Microbiology and Infectious Disseases, Istanbul 2008, p. 80.

${ }^{83}$ Nasır, İstanbul Mimarlı̆̆ında Yabancı Mimarlar, p. 54.

${ }^{84}$ Cengiz Can, "Tophane Kasrı”, Dünden Bugüne İstanbul Ansiklopedisi, Volume VII. Kültür Bakanlığı ve Tarih Vakfi Yurt Yayınları Ortak Yayın1, İstanbul 1994, p. 277.

${ }^{85}$ Haluk Şehsuvaroğlu, “İstanbul'da Yeniden İmar Edilen Tophane”, Türkiye Turing ve Otomobil Kurumu Belleteni, 181 (1957), p. 182.
} 


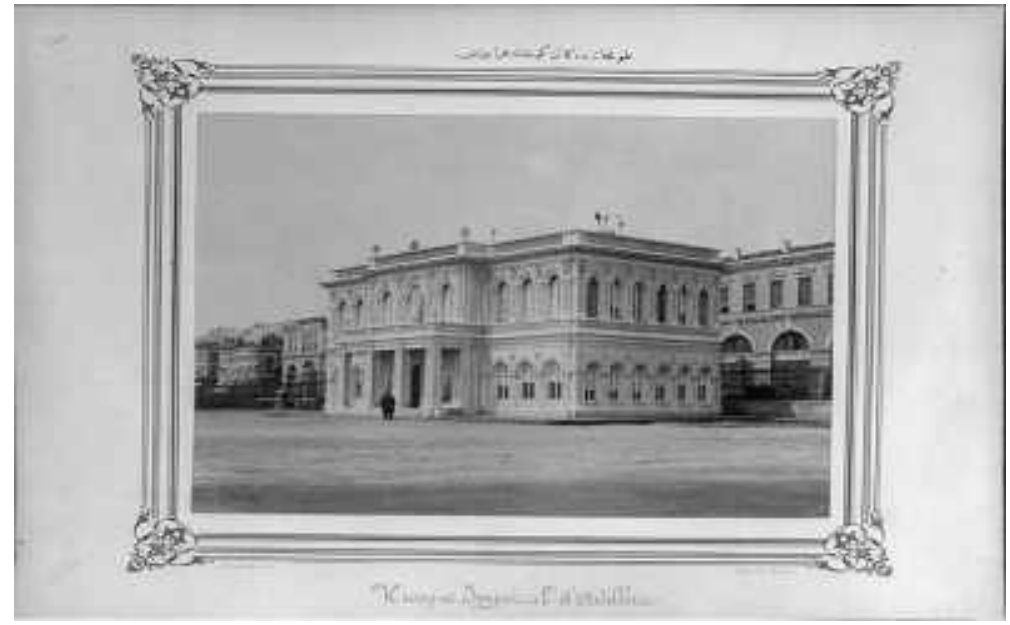

Photo 15: Tophane Kasr1, between 1880 and $1893 .{ }^{86}$

Raising over two floors, Tophane Kasrı was built in the empire style and has a rectangular plan; its entrance was slightly raised with a marble base. Smith was authorized to furnish the pavilion and he used British-style furniture to decorate it. ${ }^{87}$

\section{İbrahim Edhem Paşa Konağı}

İbrahim Edhem Pasha (1818-1893) was a Greek-Ottoman statesmen; he served in the Ottoman bureaucracy in various posts such as diplomat, governor, minister, and Grand Vizier. His son Osman Hamdi Bey was an archaeologist, painter, and the founder of Istanbul archeology museum and the Ottoman Sanayi-i Nefise Mektebi or the Fine Arts Academy. ${ }^{88}$

İbrahim Edhem Paşa Konağı, or residence, was located in Istanbul, Fatih Kantarcılar, ${ }^{89}$ around the corner of Odun Kap1 Yokuşu and Kepenekçi Sabun Hanesi. ${ }^{90}$ Today Kantarcılar is located within the precinct of Unkapanı, Küçükpazar. Konak was the first example of civilian architecture to be constructed in stone, an example of Tanzimat reforms. ${ }^{91}$ Since the early twentieth century, Konak was no longer a residence and it was used for various purposes and finally in 1967 Istanbul municipality demolished the house. After the house was demolished architect Sedad Hakk1 Eldem, who is the great grandchild of İbrahim Edhem Paşa, ${ }^{92}$ filed a complaint with the Monuments Board (Anitlar Kurulu) in 1967 stating that the architect of the building was Charles Barry, the architect of British Houses of Parliament, and that the building was one of the unique samples of civilian architecture from the Tanzimat period and he requested that the culprits of the destruction should be penalized. ${ }^{93}$ In a later work, Türk Evi Osmanlı Dönemi III (Turkish House, Ottoman Period III) in 1986, Sedad Hakk1 Eldem

\footnotetext{
86 “The Imperial Pavilion at Tophane”, Library of Congress, Abdul Hamid II Collection, LC-USZ62-82030.

${ }^{87}$ Hamzaoğlu, İstanbul'da Yabancı Bir Mimar, p. 48.

${ }^{88}$ Edhem Eldem, 'Edhem Paşa', Osman Hamdi Bey Sözlüğü, Kültür ve Turizm Bakanlığ Yayını, Ankara 2010, p. 188.

${ }^{89}$ Arzu Karahan, Ethem Paşa Konăğ Rekonstrüksiyon Projesi ve İrdelenmesi, Unpublished Master's Thesis, İstanbul Teknik Üniversitesi, İstanbul, 2010, p. 35.

${ }^{90}$ Hamzaoğlu, İstanbul'da Yabancı Bir Mimar, p. 63.

${ }^{91}$ Karahan, Ethem Paşa Konağ , p. 1.

${ }^{92}$ Mimar Sedad Hakk1 Eldem (1908-1988) was a professor at State Fine Arts Academy. He was son of Azize Hanım, who was a granddaughter of İbrahim Edhem Paşa from his son nümizmat Ali Galib Bey. Semavi Eyice, "Eldem Sedad Hakk1", Türkiye Diyanet Vakfı İslâm Ansiklopedisi, Volume XI., Türkiye Diyanet Vakfi, p. 22.

${ }^{93}$ Necdet Sakaoğlu, “İbrahim Edhem Paşa Konağı Nasıl Yapıldı, Neler Yaşadı, Nasıl Yıktırıldı?” NTV Tarih, 24 (2011), p. 64.
} 
corrected his earlier error and stated that the architect of İbrahim Edhem Paşa Konağ 1 was William James Smith. Recent work takes Eldem's 1986 work as accurate. ${ }^{94}$

İbrahim Edhem Paşa Konağı was a three-story stone building with two entrances, a large yard and an interior yard. The estimated construction date should be between 1844 and 1853, when Smith resided in Istanbul. After İbrahim Edhem Paşa's family left the building in the early 1900s, the building was first used by Numune-i Terakki Mektebi, the first private school founded by an Ottoman Turk, and later it became a storage facility for the Ottoman Red Crescent. Then, the building became a branch of Association for the Employment of Islamic Women, ${ }^{95}$ a building of Mülkiye Mektebi (Political Science School) and finally it was used as a tobacco storehouse before it was demolished in $1967 .{ }^{96}$

\section{Naum Theater}

Naum Theater was located in Flower Passage on İstiklal Street in Istanbul and it was one of the four theaters opened in the early Tanzimat period. Before the 1831 Pera fire, Aleppon merchant Michel Naum's home was in this location. The fire-damaged house became uninhabitable but an Italian acrobat still held his shows there. ${ }^{97}$ In 1840 Basilo Sansoni built a wooden theater on the land and opened its curtains as Pera Theater in 1841. After Michel Naum and his brother Joseph Naum took over the administrative control of the theater in $1844,{ }^{98}$ the theater became an important cultural location for nineteenth-century Pera; not only for the wealthy elites of the city as well as bureaucrats, but also Ottoman sultans Sultan Abdülmecid (r.1839-61) and later Sultan Abdülaziz (r.1861-76) frequented the theater. ${ }^{99}$ Even though the theater had regularly held opera and theatrical performances since 1841, physically and technically it was inadequate. In order to improve the conditions, Michel Naum personally approached Sultan Abdülmecid not only for a permission to build a new theater but also for his financial help, which was unconditionally granted in 1847. Although the Fossati Brothers were commissioned to prepare the plans of theater, for an unknown reason they could not complete the project and the task was transferred to William James Smith. ${ }^{100}$ The groundbreaking ceremony was initiated by the sultan on July $5,1847 .{ }^{101}$ The plans of this new theater building could not be located but the other documents in the Ottoman Archives along with the newspapers of the period and memoirs confirm that Smith was the architect of Naum Theater. It is possible that as the salaried employee of sultan, Smith was assigned to this sultan-funded project. The 1,200 seat-theater was completed and opened its curtains on November 4, $1848 .{ }^{102}$ After 22 years of service, it was burned down in another fire in 1870. Currently, Istanbul's famous Flower Passage stands at its location.

\section{Conclusion}

British architect William James Smith's Istanbul experience started in 1842, when he briefly visited to inspect the site for the British Embassy in Pera. In his second visit, he stayed in Istanbul from 1843 to 1853 and worked not only as the architect of British Embassy in Istanbul

\footnotetext{
${ }_{94}^{94}$ Hamzaoğlu, İstanbul'da Yabancı Bir Mimar, p.63. Karahan, Ethem Paşa Konă̆ı, p. 23.

${ }^{95}$ Kadınları Çalıștırma Cemiyet-i İslamiyesi.

${ }^{96}$ Karahan, Ethem Paşa Konağ

${ }^{97}$ Metin And, “Naum Tiyatrosu” Dünden Bugüne İstanbul Ansiklopedisi, Volume VI. Kültür Bakanlığı ve Tarih Vakfı Yurt Yayınları Ortak Yayını, İstanbul 1994, p. 52.

${ }^{98}$ Arac1, Naum Tiyatrosu, p. 81.

${ }^{99}$ Duhani, Eski Insanlar Eski Evler, p. 84.

${ }^{100}$ Cengiz Can claims that Naum Theater was a project of Fossati Brothers and William James Smith just did repairs in 1853. Cengiz Can, "Naum Tiyatrosu Mimari”, Dünden Bugüne İstanbul Ansiklopedisi, Volume IV., Kültür Bakanlığı ve Tarih Vakfi Yurt Yayınları Ortak Yayını, İstanbul 1994, p. 52-53.

${ }^{101}$ Said N. Duhani inaccurately states that Willam James Smith repaired Naum Theater after it was burned in the 1853 fire. Duhani, Eski Insanlar Eski Evler, p. 86. The theater was burned in 1853 but Smith was not the one who did the repairs. Smith worked in the construction of the theater in 1847 and left Istanbul in 1853.

${ }^{102}$ Arac1, Naum Tiyatrosu, p. 107.
} 
but also as a paid architect of Sultan Abdülmecid. Although Smith does not have a single project in the historical peninsula of Istanbul or outside Istanbul, he constructed a considerable number of buildings in the environs of peninsula, which are considered parts of city today. Like his contemporary architects from abroad, Smith introduced European architectural principles, plan, shapes and decorations along with neoclassic features with eclectic styles in stone buildings in the architectural inventory of Istanbul. Perhaps a more accurate description would be that Smith introduced European architectural dominance with the buildings he erected in Istanbul. It should also be noted that during the establishment of this dominance Smith was voluntarily serving the Ottoman political elite with Tanzimat ideas. The Ottoman elite's changing attitude on the European-style urban development of Istanbul also influenced the other cities on the periphery of empire, such as Cairo, Damascus, and Aleppo. ${ }^{103}$ Major Ottoman cities gradually embraced the three main goals of nineteenth century European urban development: safety, beauty, and health. As urban development was being pursued, it became necessary to initiate new laws and regulations to ease transformation.

Previous biographical works of William James Smith conducted in Turkey did not mention Smith's architectural history book, A Synopsis of the Origin and Progress of Architecture. This study analyzed Smith's 1831 book and added the title "architectural historian" to his biography.

The article outlined major differences between Smith's architectural practice and traditional Ottoman architecture. Despite its multinational characteristics with ethnically and religiously diverse architects, traditional Ottoman architecture was mainly commissioned by the Ottoman ruling elite and presented the official Ottoman identity. In the Tanzimat period, the political elite unconditionally accepted the technical superiority of Europe and embraced European ideas, which paved the road for the European-style urban development of Istanbul. In this juncture Smith became an important vessel to carry European architecture in general and Anglo-Saxon architecture in particular to Istanbul. He also made his structures more noticeable in the East with his eclectic approach and European-style interior designs.

Non-Ottoman architects in general and Smith in particular did not carry the pre-modern vision, which regarded Ottoman architecture as equivalent of Turkish architecture. ${ }^{104}$ This is not necessarily a negative approach and should not be regarded as interventionist. Only more objective and calm approaches can help to further the understanding of nineteenth-century Ottoman architecture history.

\section{Bibliography}

\section{A-Archival Documents}

Başbakanlık Osmanlı Arşivi, Irade-i Hariciye (İ.HAR), 33/1527, Tarih: 28 Safer 1262 (25 Şubat 1846).

Başbakanlık Osmanlı Arşivi, İrade-i Hariciye (İ.HAR), 35/1605, Tarih: 14 Cemaziyelevvel 1262 (10 Mayıs 1846).

\footnotetext{
${ }^{103}$ A general approach to the Ottoman periphery assumes that compared to Istanbul the periphery was backward not only in architecture but also in cultural and social development. Since centralization of the political authority was initiated in the Tanzimat period, the periphery might be behind this political development but in terms of cultural and social developments and trends major cities like Cairo, Damascus, and Aleppo were in the same level. For example, the eighteenth century Ottoman trend of mesire or picnic entered the social life of Damascus simultaneously with Istanbul. James P. Grehan, Everyday Life and Consumer Culture in 18th-Century Damascus, University of Washington Press, Seatle 2007, p. 23.

104 The unique concept of “Ottoman architecture as equivelant of Turkish architecture” was coined by Uğur Tanyeli. Uğur Tanyeli, “İstanbul'da Etnodinsel Çoğulluk...”, p. 60.
} 
Başbakanlık Osmanlı Arşivi, Irade-i Hariciye (I.HAR), 98/4772, Tarih: 15 Receb 1269 (24 Nisan 1853).

Başbakanlık Osmanlı Arşivi, Mühimme Kalemi Belgeleri (A.DVN.MHM), 2A/ 73, Tarih: 10 Cemaziyelahir (6 Mayıs 1846).

Library of Congress, Abdul Hamid II Collection, LC-USZ62-81696. "View of the Taşkışla Barracks of the Ministry of War", http://www.loc.gov/pictures/collection/ahii/item/2003671917/ (Date Accessed: July 25, 2015).

Library of Congress, Abdul Hamid II Collection, LC-USZ62-82030. "The Imperial Pavilion at Tophane”, http://www.loc.gov/pictures/collection/ahii/item/2003672030/ (Date Accessed: July 25, 2015).

Library of Congress, Abdul Hamid II Collection, LC-USZ62-82335. "The courtyard of the great Selimiye Barracks,” http://www.loc.gov/pictures/collection/ahii/item/2003675889/ (Date Accessed: July 25, 2015).

National Archives, Office of Works, 10-5.

National Archives, Office of Works, 40-1.

\section{B-Books and Articles}

And, Metin, "Naum Tiyatrosu”, Dünden Bugüne İstanbul Ansiklopedisi, Volume VI. Kültür Bakanlığı ve Tarih Vakfi Yurt Yayınları Ortak Yayını, İstanbul 1994, p.52-53.

Aracı, Emre, Naum Tiyatrosu: 19. Yüzyıl İstanbulu'nun İtalyan Operası, Yapı Kredi Yayınları, İstanbul 2010.

Aslanapa, Oktay, Türk Sanatı, Remzi Kitabevi, İstanbul 2003.

Atalan, Özlem, "17. ve 18. Yüzyılda Görsel ve Yazılı Kaynaklara Göre Ortaköy- Kuruçeşme Arasinda Yer Alan Kiyı Yapıları", The Journal of Academic Social Sciences (JASS), 2014 (28), pp. 225-251.

Başgelen, Nezih, Galata- Pera, Arkeoloji ve Sanat Yayınları, İstanbul 2003.

Batur, Afife, "Taşkışla İçin Küçük Bir Tarih", in Prof. Doğan Kuban'a Armağan, (Yay Haz.) Zeynep Ahunbay, Deniz Mazlum, Kutgün Eyüpgiller, Eren Yayıncılık, İstanbul 1996, p. 117-123.

Batur, Afife, "Taşkışla", Dünden Bugüne İstanbul Ansiklopedisi, C. VII. Kültür Bakanlığı ve Tarih Vakfı Yurt Yayınları Ortak Yayını, İstanbul 1994, p. 221-223.

Brodie, Antonia, Directory of British Architects, 1834-1914: Vol. 2 (L-Z), (Ed.) British Architectural Library, Royal Institute of British Architects, London 2001.

Can, Cengiz, “Naum Tiyatrosu Mimari”, Dünden Bugüne İstanbul Ansiklopedisi, Volume VI. Kültür Bakanlığı ve Tarih Vakfı Yurt Yayınları Ortak Yayını, İstanbul 1994, p. 52-53.

Can, Cengiz, "Tanzimat ve Mimarlık" in Osmanlı Mimarlı̆̆ının 7 Yüzyıll: Uluslarüstü Bir Miras”, (Yay Haz.) Nur Akın, Afife Batur, Selçuk Batur, Yem Yayın, İstanbul, 1999, p. 130-136.

Can, Cengiz, "Tophane Kasrı”, Dünden Bugüne İstanbul Ansiklopedisi, Volume VII. Kültür Bakanlığı ve Tarih Vakfı Yurt Yayınları Ortak Yayını, İstanbul 1994, p. 277.

Cezar, Mustafa, Sanatta Batı'ya Açılış ve Osman Hamdi Bey, Ak Yayınları, İstanbul 1971.

Cezar, Mustafa, XIX. Yüzyıl Beyoğlusu, Ak Yayınları, İstanbul 1991. 
Crinson, Mark, Empire Building: Orientalism and Victorian Architecture, Routledge, London 1996.

Crook, J.M. and M.H. Port, The History of King's Works, 1782-1815, Vol. 6, HMJS, London 1973.

Çalış, Bahar Deniz, Ideal and Real Spaces of Ottoman Imagination: Continuity and Change in Ottoman Rituals of Poetry (Istanbul, 1453-1730), Unpublished Dissertation, Ortadoğu Teknik Üniversitesi, Fen Bilimleri Enstitüsü, Ankara 2004.

Duhani, Said N., Eski Insanlar, Eski Evler: 19. Yüzyılın Sonunda Beyoğlu'nun Sosyal Topoğrafyasl, (Çev.) Ahmet Parman, Türkiye Otomobil ve Turing Kurumu, İstanbul 1984.

Eldem, Edhem, "Edhem Paşa”, Osman Hamdi Bey Sözlüğü, Kültür ve Turizm Bakanlığı Yayını, Ankara 2010, p. 188.

Ellsworth, De Kay, James, Sketches of Turkey in 1831-1832, J \& J. Harper, New York 1833.

Ertuğrul, Ali Dost, “XIX. Yüzyılda Osmanlı'da Ortaya Çıkan Farklı Yapı Tipleri”, Türkiye Araştırmaları Literatür Dergisi (TALID), 7/13, 2009, p. 293-312.

Eyice, Semavi, "Eldem Sedad Hakkı", Türkiye Diyanet Vakfi İslâm Ansiklopedisi, Vol. XI. Türkiye Diyanet Vakfi, p. 22-23.

Eyüpgiller, Kemal Kutgün, "İngiliz Elçiliği Binası ve Mimar Willam James Smith”, Yapı Dergisi, Say1: 268, 2004, p. 58-62.

Goodwin, Godfrey, Osmanlı Mimarlığı Tarihi, (Çev.) Müfit Günay, Kabalcı Yayınevi, İstanbul 2012.

Graves, Algernon, The Royal Academy of Arts: A Complete Dictionary of Contributors and Their Work from Its Foundation in 1769 to 1904, Vol 7, Graves \& Bell, London 1905. https://archive.org/details/royalacademyofar07grav (Date accessed: July 22, 2015).

Grehan, James P., Everyday Life and Consumer Culture in $18^{\text {th }}$-Century Damascus, University of Washington Press, Seatle 2007.

Hamadeh, Shirine, Şehr-i Sefa 18. Yüzyılda İstanbul, İletişim Yayınları, İstanbul 2010.

Hamzaoğlu, Canan, İstanbul'da Yabancı Bir Mimar William James Smith, Unpublished Master's Thesis, İstanbul Teknik Üniversitesi, Fen Bilimleri Enstitüsü, İstanbul 1996.

Hardwicke, Robert, Hardwicke's Shilling Handy-Book of London, S. Hardwicke, London 1865. https://play.google.com/store/books/details?id=Tx9bAAAAcAAJ\&rdid=bookTx9bAAAAcAAJ\&rdot=1 (Date accessed: July 22, 2015).

İgüs, Esma, "XVIII. Yüzyıl İstanbul'unda Fiziki Çevre, Meydan Çeşmeleri ve Çeşme Meydanlarının Etrafinda Oluşan İstanbul Meydanları" in Osmanlı İstanbul'u II, II. Uluslararası Osmanlı Ístanbul'u Sempozyumu Bildirileri 27-29 Mayıs 2014, İstanbul 29 Mayıs Üniversitesi, İstanbul 29 Mayıs Üniversitesi Yayınlar1, İstanbul 2015, p. 675-692.

İrez, Feryal and Hüsamettin Aksu, Boğaziçi Sefarethaneleri, Yapı Kredi Yayınları, İstanbul 1992.

Jordan, David P., Transforming Paris: The Life and Labors of Baron Hausmann, The Free Press, New York 1995.

Karahan, Arzu, Ethem Paşa Konă̆ Rekonstrüksiyon Projesi ve Irdelenmesi, Unpublished Master's Thesis, İstanbul Teknik Üniversitesi, İstanbul 2010.

Kuban, Doğan, Osmanlı Mimarisi, Yem Yayın, İstanbul 2007. 
Loudon, John Cladius, Architectural Magazine and Journal of Improvement in Architecture, Building and Furnishing and in the Various Arts and Trades Connected Therewith, V. I., (Ed.) Longman Rees, Orme, Brown, Green \& Longman, London, 1834. https://play.google.com/books/reader?id=DotAAAAAYAAJ\&printsec=frontcover\&out put=reader\&hl=en\&pg=GBS.PP1 (Date Accessed: July 29, 2015).

MacFarlane, Charles, Turkey and Its Destiny: The Result of Journeys Made in 1847 and 1848 to Examine Into the State of that Counrty, Lea and Blanchard, Philadelphia 1850. https://archive.org/details/turkeyitsdestiny02macfuoft (Date accessed: July 22, 2015).

Melling, Antoine Ignace, Voyage pittoresque de Constantinople et des rives du Bosphore, Strassburg and London: Treuttel et Würtz, [1809]-1819. http://gallica.bnf.fr/ark:/12148/bpt6k9400424k (Date accessed: July 25, 2015).

Micklewright, Nancy, "Turkey", The Oxford Companion to the Photograph (ed. Robin Lenman), Oxford University Press, Oxford 2005, pp. 634-36.

Nasır, Ayşe, İstanbul Mimarlı̆̆ında Yabancı Mimarlar, Unpublished Dissertation, İstanbul Teknik Üniversitesi, Fen Bilimleri Enstitüsü, İstanbul 1991.

Öncel, Ayşe Derin, Apartman, Galata’da Yeni Bir Konut Tipi, Kitap Yayınevi, İstanbul 2010.

Özgüven, Burcu, "İngiltere Elçiliği Binası", Dünden Bugüne İstanbul Ansiklopedisi, C. IV. Kültür Bakanlığı ve Tarih Vakfı Yurt Yayınları Ortak Yayını, İstanbul 1994, p. 175.

Pabuçcu, Merve, “Osmanlı Devleti’nde Askerî Hastaneler (1876-1908)”, Cappadocia Journal of Social Sciences, 3 (2014), pp. 85-100.

Papendiek, Charles Edward Ernest, A Synopsis of Architecture, for the Information of the Student and Amateur, Priestley and Weale, London 1826. http://babel.hathitrust.org/cgi/pt?id=uc1.c034841378;view=1up;seq=5 (Date Accessed: July 22, 2015).

Roth, Lealand M. and Amanda C. Roth Clark, Understanding Architecture: Its Elements, History, and Meaning, Westview Press, Boulder 2014.

Sakaoğlu, Necdet, “İbrahim Edhem Paşa Konağı Nasıl Yapıldı, Neler Yaşadı, Nasıl Yıktırıldı?”, NTV Tarih, 24 (2011), p. 59-65.

Savage, Nicholas and Gerald Beasley, Alison Shell, John Meriton Coast and Paul W. Nash, Early Printed Books 1478-1840, Catalogue of the British Library Early Imprints Collection, Vol. 4 (S-Z). Ed. K. G. Saur, München 2001.

Savage, Nicholas and Gerald Beasley, Alison Shell, John Meriton Coast and Paul W. Nash, Early Printed Books 1478-1840, Catalogue of the British Library Early Imprints Collection, Vol. 3 (M-R). Ed. K. G. Saur, München 2001.

Smith, Albert, A Month at Constantinople, David Bogue, London 1850. https://archive.org/stream/monthatconstanti00smit\#page/n5/mode/2up (Date accessed: July 22, 2015).

Smith, William James, A Synopsis of the Origin and Progress of Architecture, A. J. Valpy, London 1831. https://archive.org/details/asynopsisorigin00smitgoog (Date Accessed: July 22, 2015).

Şehsuvaroğlu, Haluk, “İstanbul'da Yeniden İmar Edilen Tophane”, Türkiye Turing ve Otomobil Kurumu Belleteni, 181 (1957), pp. 181-184.

Tanyeli, Uğur, "İstanbul'da Etnodinsel Çoğulluk ve Osmanlı Mimarlığı (15.-19. Yüzyı1): Rumlar, Ermeniler, Türkler”, in Batılılaşan İstanbul'un Rum Mimarları (Yay. Haz.) 
Hasan Kuruyazıc1- Eva Şarlak, Zoğrafyon Lisesi Mezunları Derneği Yayını, İstanbul 2010.

Thomas, Joseph, Universal Pronouncing Dictionary of Biography and Mythology, V. II., J. B. Lippincot, Philadelphia 1870. https://archive.org/details/universaldict02thomrich (Date accessed: July 25, 2015).

Tuztaşı Uğur and Civelek Yusuf, "Yüksek Kültürden Halk Kültürüne: Batı Mimarlığında "Ulusal Anıt" Düşüncesi ve Vernaküler Mimarinin İdealleştirilmesi", Uluslararası Sosyal Araştırmalar Dergisi, 4/18 (2011), pp. 274-289.

Tuztaşı, Uğur and İlgi Yüce Aşkun, "Klasik Dönemden Batılılaşmaya Osmanlı Mimarlığında İdealleştirme Olgusu ve Batı Mimarlığıyla Olan Mukayesesi”, Osmanlı Araştırmaları, The Journal of Ottoman Studies, 38 (2011), pp. 213-235.

Umur, Süha, "Abdülmecit, Opera ve Dolmabahçe Saray1 Tiyatrosu”, Milli Saraylar Dergisi, 1987/1, pp. 43-59.

Üsdiken, Behzat, Pera'dan Beyoğlu'na: 1840-1955, Akbank Kültür Sanat Kitapları, İstanbul 1999.

Vernoit, Stephen, "Western Asia and Arab Lands", in History of Humanity, The Nineteenth Century, Volume VI (Ed. by) Peter Mathias, Nikloai Todorov, Routledge, London 2005, pp. 227-234.

Woodword, Michelle L., "Between Orientalist Clichés and Images of Modernization: Photographic Practice in Late Ottoman Era”, History of Photography, 27/4, 2003, pp. 363-74.

Yanardağ, M. Özgür, “19. Yüzyı1 Osmanlı Devleti Para Düzeni: Kâğıt Para Kullanımına Geçiş Aşamalarının İktisadi Analizi”, Uluslararası Sosyal Araştırmalar Dergisi, 8/36 (2015), pp. 918-33.

Yazıcı, Nurcan, Osmanlılarda Mimarlık Kurumunun Evrimi ve Tanzimat Dönemi Mimarlık Ortamı, Unpublished Dissertation, Mimar Sinan Güzel Sanatlar Üniversitesi, İstanbul 2007.

Yıldırım, Nuran, A Tour of the History of Medicine in Istanbul Taksim- Beyoğlu- Üsküdar, Turkish Society of Clinical Microbiology and Infectious Disseases, Istanbul 2008. 